\title{
STUDI HYGIENE SANITASI JASABOGA DI WILAYAH BUFFE R KANTOR KESEHATAN PELABUHAN KELAS II TANJUNG INTAN CILACAP TAHUN 2017
}

\author{
Rifandi Sudariyono $^{*}$,Tri Marthy Mulyasari ${ }^{* *}$ \\ Jurusan Kesehatan Lingkungan, Politeknik Kesehatan Kemenkes Semarang, \\ Jl.Raya Baturaden KM 12 Purwokerto, Indonesia
}

\begin{abstract}
Abstrak
Jasaboga adalah usaha pengelolaan makanan yang disajikan di luar tempat usaha atas dasar pesanan yang dilakukan oleh perseorangan atau badan usaha.Hygiene sanitasi makanan dan minuman merupakan salah satu upaya penting untuk menghindari pencemaran terhadap hasil produksi ke konsumen. Tujuan penelitian ini adalah untuk mendeskripsikan hygiene sanitasi jasaboga di Wilayah Buffer Kantor Kesehatan Pelabuhan Kelas II Tanjung Intan Cilacap.Metode penelitian menggunakan penelitian deskriptif dengan menggambarkan tentang hygiene sanitasi jasaboga di wilayah buffer Kantor Kesehatan Pelabuhan Kelas II Tanjung Intan Cilacap. Penelitian dilakukan dengan cara observasi dan wawancara langsung terhadap pemilik jasaboga.Hasil penelitian didapatkan dari lima jasaboga dengan beberapa faktor suhu, pencahayaan, personal hygiene dan sanitasi jasaboga didapatkan dua jasaboga dikatagorikan memenuhi syarat dengan bobot nilai 80 dan 79, dan tiga jasaboga lainnya tidak memenuhi syarat dengan nilai 68, 69, dan 70 yang diakibatkan dari beberapa faktor personal hygiene masih belum atau penggunaan APD belum lengkap seperti masker, sarung tangan masak, penutup kepala, dan celemek, sarana untuk pengelolaan makanan seperti ventilasi yang kurang memadahi untuk tempat pengolahan makanan.Berdasarkan observasi, hasil penilaian checklist hygiene sanitasi jasaboga di wilayah buffer Kantor Kesehatan Pelabuhan Kelas II Tanjung Intan Cilacap memenuhi syarat dengan nilai bobot 80 dan 79 dari 31 komponen yang dinilai. Menurut PERMENKES Nomor 1096/Menkes/PER/VI/2011 tentang Hygiene Sanitasi Jasaboga batas minimal nilai bobot 74 untuk jasaboga golongan A2.Tahap hygiene sanitasi yang harus diperbaiki yaitu kelengkapan APD pada personal/ penjamah makanan, sarana dan prasarana yang sesuai jasaboga golongan A2.
\end{abstract}

Kata kunci:hygiene; sanitasi; jasaboga;kesehatanlingkungan

\begin{abstract}
[THE STUDY OF HYGIENE AND SANITATION IN THE REGION JASABOGATHE PORT HEALTH OFFICE OF THE BUFFERCLASS II TANJUNG INTAN CILACAPThe YEAR 2017]Jasaboga business is the management of the food that is served outside the place of business on the basis of an order made by an individual or a business entity. Hygiene, sanitation, food and drink is one of the important efforts to avoid the pollution against the results of production to consumers. The purpose of this study was to describe the hygiene sanitary jasaboga in the region of the port Health Office of the Buffer class II Tanjung Intan Cilacap.Descriptive research using research methods by describing about hygiene, sanitation, jasaboga in the region of the port Health Office of the buffer class II Tanjung Intan Cilacap. Research done by observation and direct owner checklist jasaboga.The research results obtained from five jasaboga with several factors temperature, lighting, personal hygiene and sanitation jasaboga obtained two jasaboga is found eligible by weighting the values of 80 and 79, and three other jasaboga are not eligible with a value of 68, 69, 70 and resulting from multiple factors, personal hygiene or the use of the APD has still not yet complete such as masks, gloves, headdress, and apron, a means for the management of food such as vent less memadahi for food processing.Based on observation, the results of the assessment checklist hygiene sanitary jasaboga in the region of the port Health Office of the buffer class II Tanjung Intan Cilacap qualifies with aggregate weight of 80 and 79 from 31 components are assessed. According to PERMENKES Number 1096/Menkes/PER/VI/2011 about Hygiene, sanitation,
\end{abstract}


Jasaboga minimum value weighting 74 for jasaboga the A2. Sanitary hygiene phase to be fixed IE the completeness of the APD on a personal food, facilities and infrastructure in accordance jasaboga the A2.

Keywords:hygiene; sanitation;jasaboga;environmenthal health

\section{Pendahuluan}

Makanan merupakan hal yang pokok bagi manusia, karena makanan adalah sumber tenaga bagi manusia untuk melakukan aktivitas atau kegiatan seharihari.Makanan bisa dapat diolah sendiri maupun membeli atau memesan kepada jasa yang menyediakan disebut jasaboga.Jasaboga adalah usaha pengelolaan makanan yang disajikan di luar tempat usaha atas dasar pesanan yang dilakukan oleh perseorangan atau badan usaha (Permenkes RI, 2011).

Upaya kesehatan yang terpadu dan menyuluruh dalam bentuk upaya kesehatan perseorangan dan upaya kesehatan masyarakat sebagaimana disebutkan dalam Undang-Undang Kesehatan Nomor 36 Tahun 2009 Pasal 47 dilaksanakan untuk mewujudkan derajat kesehatan yang setinggi-tingginya bagi masyarakat, melalui berbagai kegiatan diantaranya adalah pengamanan makanan dan minuman. Upaya pengamanan dalam menjaga dan meningkatkan derajat kesehatan dilakukan secara berhasil guna.Semua itu merupakan upaya untuk melindungi masyarakat dari makanan dan minuman yang tidak memenuhi peryaratan mutu (UU Nomor 36 Tahun 2009).

Tindakan hygiene sanitasi merupakan bagian dari kesehatan lingkungan.Hygiene sanitasi makanan dalam kegiatan proses produksi makanan dan minuman, merupakan salah satu upaya penting untuk menghindari pencemaran terhadap hasil produksi. Terdapat enam prinsip hygiene dan sanitasi yang harus diperhatikan dalam proses pengolahan makanan dan minuman yaitu pemilihan bahan makanan, penyimpanan makanan, pengolahan makanan, penyimpanan makanan masak, pengangkutan makanan dan penyajian makanan (Depkes RI, 2004).

Kantor Kesehatan Pelabuhan memiliki peran yang sangat penting dalam menciptakan kondisi lingkungan pelabuhan yang sehat.Salah satu upaya yang dilakukan, yaitu melakukan pemantauan tempat pengolahan makanan (TPM) di pelabuhan. Pemantauan Tempat Pengolahan Makanan (TPM) dilakukan setiap bulan baik di kantor induk maupun di Wilayah Kerja. Pemantauan TPM ini meliputi pemeriksaan fisik bangunan, bahan makanan, makanan jadi, sarana sanitasi, sertifikat kesehatan, dan personal hygiene (KKP Cilacap, 2003).

Berdasarkan laporan tahunan Kantor Kesehatan pelabuhan Kelas II Cilacap pada tahun 2016 untuk

\footnotetext{
${ }^{*}$ E-mail: Rffandi.sudariyono@gmail.com

${ }^{* *}$ E-mail: sari kirana06@yahoo.co.id
}

wilayah buffer terdapat 5 jasaboga A2 dan kegiatan pemeriksaan sampel makanan atau minuman yang diambil dari tempat pengolahan makanan atau jasaboga A2 hanya dilakukan dengan pengujian sampel makanan secara kimia. Sedangkan pemeriksaan organoleptic dan pemeriksaan bakteriologi tidak dilakukan.Hasil pemeriksaan sampel makanan atau minuman secara kimia yang meliputi formalin, methil yellow, dan rodamin-bmenunjukkan hasil yang negatif.Untuk wilayah Perimeter sebagian besar warung sederhana yang melayani konsumen ditempat tidak melayani pesanan diluar tempat usaha, maka dari itu bukan tergolong jasaboga A2 dengan kondisi bangunan, tempat pengolahan dan tempat penyajian makanan terbuka kontak langsung dengan udara luar, serta penjamah makanan tidak memenuhi personal hygiene. Oleh karena itu pihak KKP melakukan pembinaan baik dari aspek penataan bangunan, pengolahan makanan, dan juga dari aspek sanitasi sarana pengolahan makanan (KKP Cilacap, 2013). Atas dasar survey pendahuluan, maka peneliti bermaksud melakukan penelitian dengan judul "Study Hygiene Sanitasi Jasaboga di Wilayah Buffer Kantor Kesehatan Pelabuhan Kelas II Tanjung Intan Cilacap”.

\section{Bahan dan Metode}

Penelitian ini bersifat deskriptif dengan tujuan untuk mendeskripsikan Hygiene Sanitasi Jasaboga A2 di Wilayah Buffer Kantor Kesehatan Pelabuhan Kelas II Tanjung Intan Cilacap dengan menganalisis semua data yang diolah dan dibandingkan dengan PERMENKES Nomor 1096 tahun 2011 tentang hygiene sanitasi jasaboga.Pengumpulan data yang dilakukan dalam penelitian ini adalah dengan cara observasi, wawancaradan dokumen Kantor Kesehatan Pelabuhan Cilacap.

\section{Hasil dan Pembahasan}

Berdasarkan hasil penelitian yang dilakukan pada Sanitasi Jasaboga A2 di Wilayah Buffer Kantor Kesehatan Pelabuhan Kelas II Tanjung Intan Cilacapdapat dilihat pada hasil dan pembahasan berikut ini:

a. Pengukuran Suhu

Rekapitulasi hasil pengukuran suhu pada 5 jasaboga

$\underline{\text { Tabel } 4.1 \text { rekapitulasi pengukuran suhu pada } 5 \text { jasaboga }}$

$$
\begin{array}{clc}
\text { No. Jasa } & \text { Suhu } \\
\text { boga } & \text { (Celcius) } & \begin{array}{c}
\text { Memenuhi Syarat Atau Tidak } \\
\text { Memenuhi Syarat }
\end{array}
\end{array}
$$




\begin{tabular}{cccc}
\hline 1 & $\mathrm{~A}$ & $32,7^{\circ} \mathrm{C}$ & Tidak memenuhi syarat \\
\hline 2 & $\mathrm{~B}$ & $33,5^{\circ} \mathrm{C}$ & Tidak memenuhi syarat \\
\hline 3 & $\mathrm{C}$ & $32,2^{\circ} \mathrm{C}$ & Tidak memenuhi syarat \\
\hline 4 & $\mathrm{D}$ & $31,4^{\circ} \mathrm{C}$ & Memenuhi syarat \\
\hline 5 & $\mathrm{E}$ & $32,3^{\circ} \mathrm{C}$ & Tidak memenuhi syarat \\
\hline
\end{tabular}

Tabel 4.1 dapat dilihat hasil pengukuran suhu kelima jasaboga sudah memenuhi syarat, karena syarat suhu kenyamanan pada jasaboga $28^{\circ} \mathrm{C}-32^{\circ} \mathrm{C}$ pada PERMENKES Nomor 2011 tentang hygiene sanitasi jasaboga.

b. Pengukuran Instensitas Cahaya

tabel 4.2 Rekapitulasi Pengukuran Intensitas Pencahayaan

No. Jasa Pencahayaan Memenuhi Syarat Atau

\begin{tabular}{lll} 
No. boga & (Lux) & Tidak Memenuhi Syarat \\
\hline
\end{tabular}

\begin{tabular}{cccc}
\hline 1 & A & 9 Lux & Tidak memenuhi syarat \\
\hline 2 & B & 237 Lux & Memenuhi syarat \\
\hline 3 & C & 181 Lux & Tidak memenuhi syarat \\
\hline 4 & D & 10 Lux & Tidak memenuhi syarat \\
\hline 5 & E & 21 Lux & Tidak memenuhi syarat \\
\hline
\end{tabular}

Hasil table 4.2 rekapitulasi pengukuran intensitas cahaya pada kelima jasaboga menunjukan 1 (satu) memenuhi syarat dan 4 (empat) tidak memenuhi syarat. Sebab syarat standar pencahayaan suatu jasaboga minimal $20 \mathrm{fc}$ (foot candle meter) atau 200lux, PERMENKES Nomor 1096 tahun 2011 tentang hygiene sanitasi jasaboga.

c. Personal Hygiene Jasaboga A2 Wilayah Buffer Personal Hygiene orang yang secara langsung berhubungan dengan makanan dan peralatan mulai dari tahap persiapan, pembersihan, pengolahan, pengangkutan sampai penyajian makanan, PERMENKES nomor 1098 tahun 2003 tentang persyaratan hygiene sanitasi rumah makan dan restoran. Tabel 4.3 Rekapitulasi Personal Hygiene Jasaboga A2

\begin{tabular}{lcccc}
\hline & & \multicolumn{3}{c}{ Kriteria } \\
\cline { 3 - 5 } No. Jasaboga & $\begin{array}{l}\text { Jumlah Penjamah } \\
\text { Makanan }\end{array}$ & $\begin{array}{l}\text { Score } \\
(\%)\end{array}$ & Ktiteria \\
\hline 1. & I & 6 & 94,4 & Baik \\
\hline 2. & II & 3 & 94,4 & Baik \\
\hline 3. & III & 5 & 88,9 & Baik \\
\hline 4. & IV & 2 & 72,2 & Cukup Baik \\
\hline 5. & V & 5 & 77,8 & Baik \\
\hline
\end{tabular}

Hasil tabel 4.3 menunjukan personal hygiene sanitasi jasaboga A2 dari lima jasaboga yang diteliti yaitu jasaboga I dan II dengan nilai skore atau presentasi 94,4\%. Kriteria penilaian diambil menurut Suharsini Arikunto (1998, h.248) dengan acuan PERMENKES nomor 1096/Menkes/PER/VI/2011 tentang Hygiene Sanitasi Jasaboga.

d. Sanitasi Jasaboga A2 di Wilayah Buffer

Sanitasi Jasaboga A2 di Wilayah Buffer didapatkan hasil observasi dengan penilaian skor/prosentasi checklist, berikut tabel hasil skor/prosentase penilaian Sanitasi Jasaboga A2.

1. Rekapitulasi Sanitasi Jasaboga

Tabel 4.4 Rekapitulasi Sanitasi Jasaboga

\begin{tabular}{cccc}
\hline No. & Jasaboga & Bobot & Kriteria \\
\hline 1. & I & 80 & Memenuhi Syarat \\
\hline 2. & II & 79 & Memenuhi Syarat \\
\hline 3. & III & 69 & $\begin{array}{c}\text { Tidak Memenuhi } \\
\text { Syarat }\end{array}$ \\
\hline 4. & IV & 70 & $\begin{array}{c}\text { Tidak Memenuhi } \\
\text { Syarat }\end{array}$ \\
\hline 5. & V & 68 & $\begin{array}{c}\text { Tidak Memenuhi } \\
\text { Syarat }\end{array}$ \\
\hline
\end{tabular}

Tabel 4.4 didapatkan hasil penilian jasaboga A2 dengan bobot tertinggi 80 dan terendah 68, dari kelima (5) jasaboga yang memenuhi syarat Jasaboga I , II dan yang tidak memenuhi syarat Jasaboga III, IV, dan V. Kriteria diambil menurut ketentuan PEREMENKES nomor 1096/Menkes/PER/VI/2011 tentang Hygiene Sanitasi Jasaboga.

2. Alat Makanan

Tabel 4.5 Rekapitulasi Alat Makanan Jasaboga A2

\begin{tabular}{lccc}
\hline No. & Jasaboga & Skor $(\%)$ & Kriteria \\
\hline 1. & I & 77,8 & Baik \\
\hline 2. & II & 100 & Baik \\
\hline 3. & III & 100 & Baik \\
\hline 4. & IV & 77,8 & Baik \\
\hline 5. & V & 77,8 & Baik \\
\hline
\end{tabular}

Hasil tabel 4.5 menunjukan kelima jasaboga pada alat makanan sudah memenuhi syarat dengan nilai skor/prosentasi $100 \%$ pada jasaboga II dan III. Kriteria penilaian diambil menurut Suharsini Arikunto (1998, h.248) dengan acuan PERMENKES Nomor 1096 tahun 2011 tentang hygiene sanitasi jasaboga.

3. Tempat Pengolahan Makanan

Tabel 4.6 Rekapitulasi Tempat Pengolahan Jasaboga A2

\begin{tabular}{cccc}
\hline No. & Jasaboga & Skor (\%) & Kriteria \\
\hline 1. & I & 100 & Baik \\
\hline 2. & II & 100 & Baik \\
\hline 3. & III & 100 & Baik \\
\hline 4. & IV & 89,4 & Baik \\
\hline 5. & V & 100 & Baik \\
\hline
\end{tabular}

Tabel 4.6 didapatkan kelima Jasaboga A2 pada tempat pengolahan sudah memenuhi syarat. Kriteria penilaian diambil menurut Suharsini Arikunto (1998, h.248) dengan acuan PERMENKES Nomor 1096 tahun 2011 tentang hygiene sanitasi jasaboga.

4. Pemilihan Bahan Makanan

Tabel 4.7 Rekapitulasi Pemilihan Bahan Makanan Jasaboga A2

\begin{tabular}{llll}
\hline No. & Jasaboga & $\begin{array}{c}\text { Skor } \\
(\%)\end{array}$ & Kriterian \\
\hline
\end{tabular}




\begin{tabular}{cccl}
\hline 1. & I & 100 & Baik \\
\hline 2. & II & 100 & Baik \\
\hline 3. & III & 100 & Baik \\
\hline 4. & IV & 100 & Baik \\
\hline 5. & V & 100 & Baik \\
\hline
\end{tabular}

nilai skor/ prosentase $100 \%$. Kriteria penilaian diambil menurut Suharsini Arikunto (1998, h.248) dengan acuan PERMENKES Nomor 1096 tahun 2011 tentang hygiene sanitasi jasaboga.

8. Penyimpanan Makanan Jadi

Tabel 4.11 Penyimpanan Bahan Makanan

Tabel 4.7 menunjukan hasil pemilahan bahan makanan kelima Jasaboga A2 sudah memenuhi syarat dengan nilai skor/ prosentase $100 \%$. Kriteria penilaian diambil menurut Suharsini Arikunto (1998, h.248) dengan acuan PERMENKES Nomor 1096 tahun 2011 tentang hygiene sanitasi jasaboga.

5. Penyimpanan Bahan Makanan

Tabel 4.8 Rekapitulasi Penyimpanan Bahan Makanan

\begin{tabular}{cccc}
\hline No. & Jasaboga & $\begin{array}{c}\text { Skor } \\
(\%)\end{array}$ & Kriterian \\
\hline 1. & I & 100 & Baik \\
\hline 2. & II & 100 & Baik \\
\hline 3. & III & 100 & Baik \\
\hline 4. & IV & 100 & Baik \\
\hline 5. & V & 100 & Baik \\
\hline
\end{tabular}

Tabel 4.8 menunjukan hasil Penyimpanan Bahan Makanan dari kelima Jasaboga A2 sudah memenuhi syarat dengan nilai skor/ prosentase 100\%. Kriteria penilaian diambil menurut Suharsini Arikunto (1998, h.248) dengan acuan PERMENKES Nomor 1096 tahun2011 tentang hygiene sanitasi jasaboga.

6. Pengolahan Bahan Makanan

Tabel 4.9 Pengolahan Bahan Makanan

\begin{tabular}{cccc}
\hline No. & Jasaboga & Skor $(\%)$ & Kriteria \\
\hline 1. & I & 100 & Baik \\
\hline 2. & II & 100 & Baik \\
\hline 3. & III & 100 & Baik \\
\hline 4. & IV & 100 & Baik \\
\hline 5. & V & 100 & Baik \\
\hline
\end{tabular}

Tabel 4.9 menunjukan hasil pengolahan bahan makanan dari kelima Jasaboga A2 sudah memenuhi syarat dengan nilai skor/ prosentase $100 \%$. Kriteria penilaian diambil menurut Suharsini Arikunto (1998, h.248) dengan acuan PERMENKES Nomor 1096 tahun 2011 tentang hygiene sanitasi jasaboga.

\section{Pengangkutan Makanan}

Tabel 4.10 Pengangkutan Makanan

\begin{tabular}{cccc}
\hline No. & Jasaboga & Skor $(\%)$ & Kriteria \\
\hline 1. & I & 100 & Baik \\
\hline 2. & II & 100 & Baik \\
\hline 3. & III & 100 & Baik \\
\hline 4. & IV & 100 & Baik \\
\hline 5. & V & 100 & Baik
\end{tabular}

Tabel 4.10 menunjukan hasil pengangkutan makanan dari kelima Jasaboga A2 sudah memenuhi syarat dengan

\begin{tabular}{cccc}
\hline No. & Jasaboga & Skor $(\%)$ & Kriteria \\
\hline 1. & I & 100 & Baik \\
\hline 2. & II & 100 & Baik \\
\hline 3. & III & 100 & Baik \\
\hline 4. & IV & 100 & Baik \\
\hline 5. & V & 100 & Baik \\
\hline
\end{tabular}

Tabel 4.11 menunjukan hasil penyimpanan bahan makanan dari kelima Jasaboga A2 sudah memenuhi syarat dengan nilai skor/Prosentase $100 \%$. Kriteria penilaian diambil menurut Suharsini Arikunto (1998, h.248) dengan acuan PERMENKES Nomor 1096 tahun 2011 tentang hygiene sanitasi jasaboga.

9. Penyajian Bahan Makanan

Tabel 4. 12 Rekapitulasi Penyajian Makanan

\begin{tabular}{cccc}
\hline No. & Jasaboga & Skor $(\%)$ & Kriteria \\
\hline 1. & I & 100 & Baik \\
\hline 2. & II & 100 & Baik \\
\hline 3. & III & 100 & Baik \\
\hline 4. & IV & 100 & Baik \\
\hline 5. & V & 100 & Baik \\
\hline
\end{tabular}

Tabel 4.12 menunjukan hasil Penyajian Makanan dari kelima Jasaboga A2 sudah memenuhi syarat dengan nilai skor/ prosentasi $100 \%$. Kriteria penilaian diambil menurut Suharsini Arikunto (1998, h.248) dengan acuan PERMENKES Nomor 1096 tahun 2011 tentang hygiene sanitasi jasaboga.

\section{Kesimpulan}

Berdasarkan hasil penelitian dan pembahasan dapat diambil simpulan sebagai berikut :

a. Suhu

Suhu di jasaboga A2 sebagian besar masih belum memenuhi syarat dikarenakan kurangya ventilasi yang tersedia dijasaboga dan kurangnya kipas angin dan exhouseter mengakibatkan suhu disana tidak memenuhi syarat, suhu kenyamanan di jasaboga $28-32^{\circ} \mathrm{C}$ sesuai dengan PERMENKES Nomor 1096 tahun 2011 tentang Hygiene Sanitasi Jasaboga.

\section{b. Intensitas cahaya}

Pengukuran intensitas cahaya di lima jasaboga sebagian besar masih belum memenuhi syarat karena faktor kurangnya pencahayaan buatan yang memadai, kurangnya pencahayaan alami yang masuk kedalam ruangan, dan luas bangunan dengan pencahayaan disana tidak seimbang dengan baik. Maka dari itu jasaboga 
yang belum memenuhi syarat. Syarat standar pencahayaan suatu jasaboga minimal 20fc (foot candle meter) atau 200lux, PERMENKES Nomor 1096 tahun 2011 tentang Hygiene Sanitasi Jasaboga

c. Personal hygiene

Personal Hygiene di lima jasaboga A2 Kantor Kesehatan Pelabuhan Tanjung Intan Cilacap wilayah Buffer sudah memenuhi syarat dengan skore atau prosentasi 94,4\%akan tetapi sebagian penjamah atau personal hygiene masih ada yang belum menggunakan APD secara lengkap.

d. Sanitasi jasaboga A2

Sanitasi di lima (5) jasaboga wilayah bufferdidapatkan hasil penilian jasaboga A2 dari semua aspek pemilihan bahan makanan sampai penyajian makanan dan termasuk personal hygiene/ penjamah makanan dengan jumlah bobot tertinggi 80 dan terendah 68, dari kelima (5) jasaboga yang memenuhi syarat Jasaboga I , II dan yang tidak memenuhi syarat Jasaboga III, IV, dan V.

\section{Ucapan Terima Kasih}

Peneliti mengucapkan banyak terima kasih kepada Kepala Kantor Kesehatan Pelabuhan Tanjung Intan Cilacap yang telah memberikan ijin penelitian di wilayah Buffer dan pemilik jasaboga yang telah membantu menyelesaikan penelitian ini.

\section{Daftar Pustaka}

Anwar Sudarso, dkk, 1987, Sanitasi makanan dan Minuman pada Institusi Pendidikan Tenaga Sanitasi. Departemen Kesehatan Republik Indonesia. Jakarta.

Depkes RI. 2000. Persyaratan Kesehatan Boga, Jakarta.

Depkes RI. 2004. Hygiene Sanitasi Makanan dan Minuman. Ditjen PPM dan PL, Jakarta.

Keputusan Menteri Kesehatan RI. No.942/Menkes/SK/VII/2003 tentang Persyaratan Hygiene Sanitasi Makanan Jajanan.2003, Jakarta.

Keputusan Menteri Kesehatan RI No. 1098/Menkes/SK/VII/2003 tentang Persyaratan Hygiene Sanitasi Rumah Makan dan Restoran.2003, Jakarta.
(Tri Marthy Mulyasari)
Keputusan Menteri Kesehatan RI $\begin{array}{r}\text { No. } \\ \text { 1096/Menkes/PER/VI/2011 tentang Hygiene } \\ \text { Sanitasi Jasaboga.2011, Jakarta. }\end{array}$

Lutfi Nurlaily. 2014. Studi Hygine Sanitasi Makanan di Instalasi Gizi RSUD Daerah Banyumas, Purwokerto, Politeknik Kesehatan Kemenkes Semarang Jurusan Kesehatan Lingkungan.

Mulia, Ricky.M. 2005. Pengantar Kesehatan Lingkungan. Edisi pertama. Penerbit Graha Ilmu, Yogyakarta.

Palupi Rizki Amalia Putri. 2013. Studi Hygiene Sanitasi Makanan di RSUD Cilacap, Purwokerto. Politeknik Kesehatan Kemenkes Semarang Jurusan Kesehatan Lingkungan.

Tri, Cahyono. 2014, Pedoman Penulisan Proposal Penelitian dan Karya Tulis ilmiah/skripsi. Edisi Revisi Ketiga, Purwokerto, Polteknik Kesehatan Kemenkes Semarang Jurusan Kesehatan Lingkungan.

Undang-undang Republuk Indonesia Nomor 36 Tahun 2009 tentang Kesehatan. Jakarta.

Winarti, S. 2006. Makanan dan Minuman Kesehatan. Trubus Agrisarana, Surabaya. 